УДК: 330.143:631

JEL Classification: M 11

\author{
I. B. ФУРМAH, \\ кандидат економічних наук, \\ доџент кафедри адміністративного менеджменту \\ ма альтернативних джсрел енергіi, \\ Вінницький національний аграрний університет
}

\title{
Вектори підвищення ефективності управління прибутком підприсмства
}

В статті розкриваються теоретико-методологічні основи управління прибутковістю підприємств. Представлено економічну природу прибутку та його роль у забезпеченні підприсмницькой діяльності. Наведено особливості управління прибутком підприємств у сучасних умовсх. Окреслено вектори покрацення ефективності управління прибутком підприсмства.

Ключові слова: прибуток, управління прибутком, управлінські рішення, фінансовий результат діяльності підприємства, планування прибутку, система управління прибутком, організаційно-економічний механізм управління якістю прибутку підприсмства.

Актуальність теми дослідження. В умовах нестабільної економіки України, загострення кризових явищ у суспільстві виникає гостра потреба в активізації господарської діяльності та пошуку інструментів, які б дали можливість зняти соціальну напругу й забезпечити сталий розвиток реального сектору. Одним із таких інструментів $€$ прибуток, який виступає основним джерелом приросту власних фінансових ресурсів, необхідних для забезпечення фінансово-господарської діяльності суб' сктів господарювання. Прибуток підприємства $\epsilon$ провідною рушін̆ною силою ринкової економіки, джерелом власних фінансових ресурсів, необхідних для забезпечення фінансово-господарської діяльності. Їх нестача спонукає до здійснення запозичень, що у кінцевому підсумку, у разі неефективної боргової політики, може призвести до фінансової кризи і банкрутства. Зростання прибутку підприємств значною мірою впливає на темпи економічного розвитку країни, окремих регіопів, збільшення суспільного багатства і підвишення життєвого рівня населення. Саме тому проблема ефективного управління прибутком підприємств $\epsilon$ актуальним питанням для економіки України в сучасних умовах.

Недосконале управління процесами формування та використання прибуукку призводить до зниження ефективності діяльності суб'єктів господарювання та їх можливості щодо наповнення доходів бюджету. Це зумовлює необхідність пошуку нових, більш ефективних механізмів формування та використання прибутку, які б передбачали максимальне використання виробничого, маркетингового та фіскального потенціалу суб'єктів господарювання, зростання їх конкурентоспроможності на українському і світовому ринках в умовах глобалізації економічних процесів.

Аналіз останніх досліджень і публікацій. Питання управління формуванням прибутку в процесі операційної, фінансової та інвестиційної діяльності підприємства, забезпечення його оптимального розподілу та використання знайшли відображення у наукових працях вчених України та зарубіжжя: І. Бланка [1], Ю. Брігхема [2], М. Ерхардта, J. Куц [3], Н. Пігуль [4], А. Поддєрьогіна [5], С. Покропивного [6] та інших. Утім розвиток механізму управління прибутком підприємства в умовах кризових явищ потребує більш детальної систематизації як факторів впливу на процеси управління прибутком підприємств в Україні, так і тенденцій розвитку зазначених процесів. Також варто вказати, що економічна теорія і практика сьогодення свідчать, що процес формування прибутку суб' єктів господарювання, ефективність його формування й використання досліджені недостатньо, без урахування зростання відкритості економіки України та посилення впливу глобалізаційних процесів на стан економічного середовища.

(C) I. В. Фурман, 2017 
Метою статті є дослідження, на основі теоретичних узагальнень, сутності прибутку як економічної категорії та основного елемента ефективності діяльності підприємства, а також розвідка конщептуальних засад управління прибутком та аналіз системи управління прибутком підприємств.

Основıи результати дослідження. Становлення в Україпі ринкової інфраструктури суттєво впливає на зміст господарської діяльності та фінансовий стан суб'єктів господарювання. Оскільки характерною рисою сьогодення стала велика кількість збиткових підприємств, зростає потреба у дослідженні причинно-наслідкових зв"язків, пов'язаних із процесом формування й ефективпістю використання прибутку суб єктів господарювання.

В умовах ринкової економіки прибуток - одна з основних цілей підприємницької діяльності, тому визначення сутності прибутку та механізму його формування і використання $\epsilon$ необхідною передумовою теоретичного обгрунтування розвитку бізнесу в країпі. Зростання динаміки економічних відносин і глибинна трансформація іх внутрішньої природи, підвищення ролі інноваційного фактора у забезпеченні конкурентоспроможності та довгострокової результативності діяльності підприємства визначають необхідність переосмислення аналітичного інструментарію управління результативністю діяльності сучасного підприємства [7].

Науковці по-різному підходять до визначення сутності поняття “прибуток”. Так, I. Бланк, який одним із перших в У країпі використовує поняття співвідношення ризику і доходу, визначає прибуток як втілений у грошовій формі чистий доход підприємця на вкладений капітал, що характеризує його винагороду за ризик здійснення підприємницької діяльності та є різницею між сукупним доходом і сукупними витратами у процесі здійснення цієї діяльності [1].

Є. Брігхем вважає прибуток $€$ однією з основних категорій товарного виробництва. Це передусім виробнича категорія, яка характеризує відносини, що складаються у процесі суспільного виробництва [2].

А. Поддєрьогін визначає прибуток як частину заново створеної вартості, виробленої та реалізованої, готової до розподілу. Таким чином, наголошується на важливості процесу реалізації виробленого продукту за гроші [8].

Отже, незважаючи на відмінності у тлумаченні поняття “прибуток”, можна узагальнити підходи вітчизняних і зарубіжних дослідників, відобразивши роль і значення прибутку підприємства в умовах ринкової економіки (рис. 1).

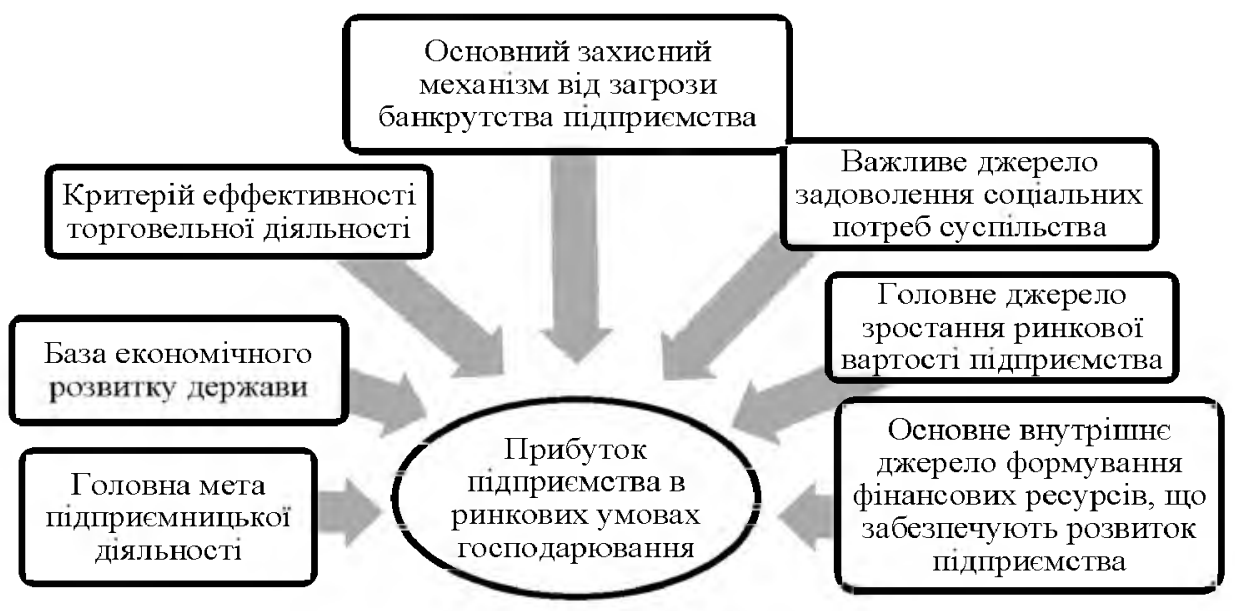
Рис. 1. Характеристика ролі прибутку пидриємства в умовах ринкової економіки України

Джерело: [9]

Як видно з рис. 1, прибуток підприємства виступає не лише як основа функцюнування окремого підприємства, а і як база економічного розвитку країни в цілому. 
Чимала роль прибутку в розвитку підприємства і забезпеченпі інтересів його власників визначає необхідпість ефективного управління ним.

Управління прибутком являс собою процес розроблення та прийняття ефективних управлінських рішень стосовно всіх основних аспектів його формування та розподілу, а також його використання на підприємстві з метою максимізації добробуту власників підприємства в поточному та перспективному періодах [1].

Головною метою управління прибутком $\epsilon$ визначення шляхів найбільш ефективного його формування та оптимального розподілу для забезпечення розвитку діяльності підприємства та зростання його ринкової вартості.

Ефективне управління прибутком підприємства можливе за наявності дієвої та правильно сформованої системи управління прибутком підприємства.

Система управління прибутком підприємством - це сукупність взаємопов 'язаних елементів, кожний з яких має функціональне призначення та спільна дія яких, за певних умов, забезпечує досягнення механізму отримання прибутку заданої величини.

Грунтуючись на різноманітних нідходах вчених можна виділити такі елементи системи управління прибутком підприємств (рис. 2).

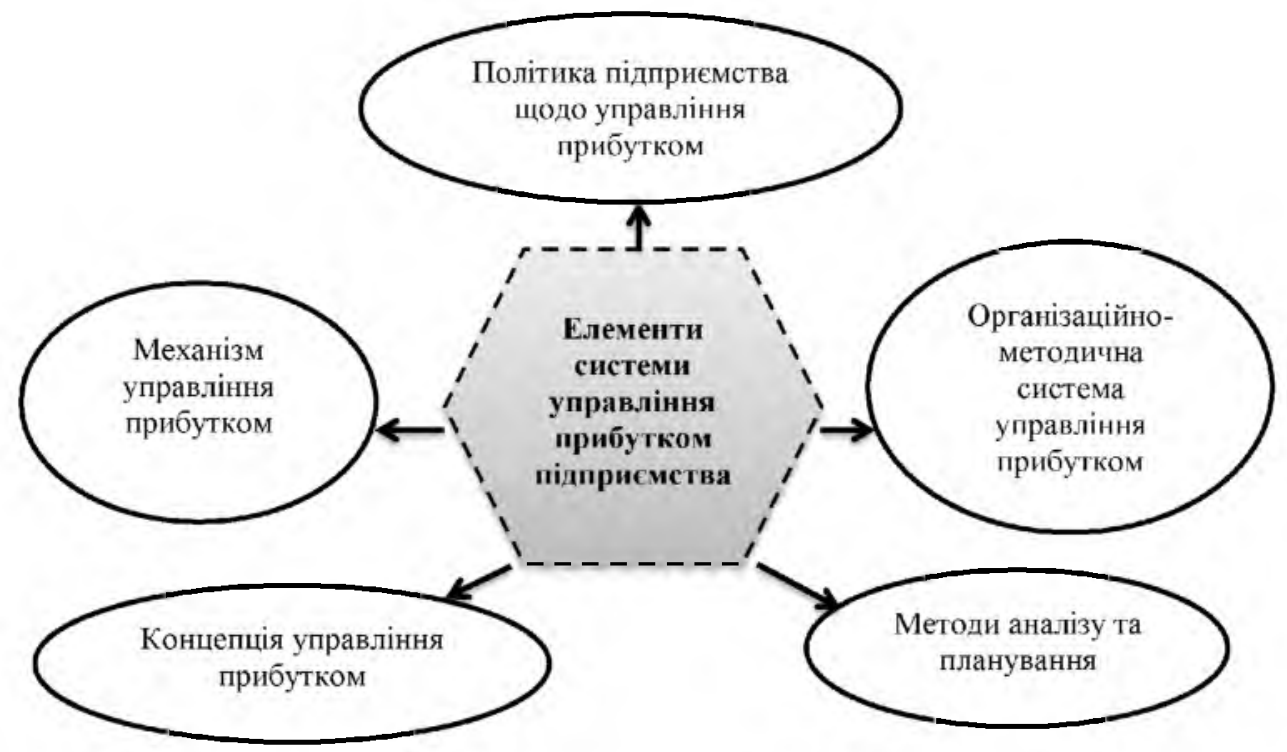

Рис. 2. Складові елементи системи управління прибутком підприсмства

Джерело: адаптовано та узагальнено автором на основі досліджень $[4 ; 11]$

Виходячи з головної мети, система управління прибутком дає змогу вирішувати такі завдання: забезпечення максимізації розміру прибутку, що формується відповідно до ресурсного потенціалу підприємства; забезпечення оптимальної пропорційності між рівнем прибутку і допустимим рівнем ризику; забезпечення високої якості прибутку; забезпечення виплат необхідного рівня доходу на інвестований капітал власникам підприємства; забезпечення формування відповідного обсягу фінансових ресурсів за рахунок прибутку відповідно до завдань розвитку підприємства на майбутній перюд; забезпечення постійного зростання ринкової вартості підприємства [6].

Управління прибутком підприємства можна визначити як сукупність фінансовоправових та організаційно-технічних механізмів і методів прогнозування, планування та контролю доходів і витрат підприємства з метою забезпечення оптимального рівня рентабельності суб єкта господарювання в довгостроковін̆ перспективі, а також досягнення інших цілей корпоративної стратегії, шо передбачає процес розроблення та прийняття управлінських рішень стосовно всіх основних аспектів формування, розподілу та використання прибутку на підприємстві.

Управління формуванням прибутку підприємства має бути цілеспрямоване на максимізацію розміру позитивного фінансового результату шляхом підвищення обсягів 
його діяльності, ефективного управління витратами, нідвищення ефективності використання матеріально-технічної бази та системи управління суб'єктом господарювання загалом. По мірі формування прибуток підприємства розподіляють та використовують, зокрема спрямовують на роботи зі створення, освоєння і впровадження нової техніки; на удосконалення технології і організації виробництва; на модернізацію обладнання; покращення якості продукції; технічне переобладнання [11].

Політика управління розподілом прибутку підприємства повинна відображати основні вимоги загальної стратегії розвитку підприємства, формувати необхідні обсяги інвестицій, а також забезпечувати матеріальні інтереси власників і працівників. Необхідно відзначити, що система управління прибутком повинна мати зворотний зв'язок із системою управління підприємства в цілому, адже управлінські рішення на рівні підприємства в будь-якому разі впливають на рівень прибутку, який є основним фінансовим джерелом розвитку підприємства.

Стратегічне управління прибутком $є$ однією із основних складових системи стратегічного менеджменту підприємств, яка визначає якість системи корпоративного управління. Стратегічне управління прибутком підприємства необхідно розглядати як комплексний процес, що передбачає реалізацію низки послідовних етанів організації, планування, аналізу та контролю прибутку для забезпечення уснішної реалізації основної мети суб' єкта господарювання, стійкого нідвищення прибутковості, ринкової вартості та досягнення довгострокового економічного розвитку підприємства [12].

Для ефективного управління прибутком необхідно сформувати дієву систему управління прибутком підприємства, яка включає взаємопов'язані функцінальні елементи, спільна дія яких за певних умов забезпечує реалізацію механізму отримання прибутку заданої величини. Ця система складається з таких основних блоків: мета, завдання та приншипи управління; інформаційне забезпечення; механізм управління; організаційне забезпечення; методи аналізу прибутку; контроль за виконанням плану прибутку.

Головною метою управління прибутком є визначення шляхів найбільш ефективного його формування та оптимального розподілу, що спрямовані на забезпечення розвитку діяльності підприємства та зростання його ринкової вартості.

Виходячи із мети управління прибутком, у процесі управління доцільно вирішити такі завдання [13]:

а) оптимізація обсягу прибутку, що відповідає ресурсному потенціалу підприємства й ринковій кон'юнктурі;

б) досягнення максимально можливої відповідності між обсягом сформованого прибутку й припустимим рівнем ризику. Між цими параметрами спостерігається прямо пропорційна залежність;

в) забезпечення високої якості сформованого прибутку. Це означає, що резерви його зростання повинні бути в першу чергу реалізовані за рахунок операційної (поточної) діяльності й реального інвестування чистого прибутку, шо створює базу для подальшого розвитку підприємства;

г) формування за рахунок прибутку обсягу фінансових ресурсів, достатніх для розвитку підприємства в майбутньому. Ці грошові ресурси концентруються в складі фонду нагромадження й спрямовуються на фінансування витрат капітального характеру;

д) розроблення ефективних програм участі персоналу в прибутку підприємства, що дозволяє зблизити інтереси власників і найманих робітників;

е) створення умов для збільшення ринкової вартості підприємства, що визначається рівнем капіталізації прибутку. Підприємство саме встановлює пропорції розподілу прибутку на частини, що капіталізуються і споживаються. При цьому враховуються умови й завдання господарської діяльності.

Необхідно зазначити, що приншипи управління прибутком залежать від багатьох факторів, головними із яких є особливості галузевої приналежності, спеціалізація нідприємства, його організаційна форма і форма власності, цілі стратегічного розвитку й етапи реалізації стратегії і т. Д. Це зумовлює, поряд із використанням загальноприйнятих принципів управління прибутком, необхідність розроблення особливих принципів для кожного конкретного підприємства. 
Вважаємо, що в основу раціонального формування та ефективного функціонування системи стратегічного управління прибутком підприємства має бути покладено комплекс фундаментальних принципів стратегічного управління прибутком підприємств (табл. 1).

Таблиия 1

Ключові принципи стратегічного управління прибутком підприсмств

\begin{tabular}{|c|c|}
\hline $\begin{array}{c}\text { Принципи стратегічного } \\
\text { управління прибутком }\end{array}$ & $\begin{array}{c}\text { Характеристика принципів стратегічного } \\
\text { управлління прибутком пндприсмств }\end{array}$ \\
\hline $\begin{array}{l}\text { Системиості та } \\
\text { ієрархічності }\end{array}$ & $\begin{array}{l}\text { Стратегічне управління прибутком є основною складо- } \\
\text { вою системи стратегічного менеджменту підприємства та } \\
\text { реалізується з урахуванням принципів і засад даної системи. }\end{array}$ \\
\hline Комплексності & $\begin{array}{l}\text { Процес прийняття ефективних управлінських рішень пе- } \\
\text { редбачає комплексне врахування умов, правил, ресурсів і } \\
\text { факторів формування приб̆уку підприємства. } \\
\end{array}$ \\
\hline Цілеспрямованості & $\begin{array}{l}\text { Важливою складовою стратегічиого управління прибут- } \\
\text { ком підприємства є інноваційно-інвестиційні проекти, } \\
\text { реалізація яких здійснюєтья у зонах стратегічних інтересів } \\
\text { та стратегічних зонах господарювання. } \\
\end{array}$ \\
\hline Ієрархічності цілей & $\begin{array}{l}\text { Процеси розподілу і використання прибутку повиииі } \\
\text { відбуватися } 3 \text { урахуванням пріоритетності тих цілей, } \\
\text { реалізація яких сприяс стійкому підвищеиню прибутковості. } \\
\text { ринкової вартості та досягненню довгострокового } \\
\text { економічного розвитку підприємства. }\end{array}$ \\
\hline Капіталовідтворения & $\begin{array}{l}\text { Важлива фуикція стратегічного управліиия прибутком } \\
\text { спрямована на забезпечення перманентного відтворення та } \\
\text { зростання вартості капіталу підприємства. }\end{array}$ \\
\hline Активності & $\begin{array}{l}\text { Для забезпечення стійкого підвищення прибутковості, ринко- } \\
\text { вої вартості та досягнення довгострокового економічного роз- } \\
\text { витку підприємству необхідно здійснювати цілеспрямований } \\
\text { вплив на зовнішнє середовище з метою створення найбільш } \\
\text { сприятливих умов для успішиої реалізації основних цілей } \\
\text { його діяльності. } \\
\end{array}$ \\
\hline $\begin{array}{l}\text { Розвитку виробничо- } \\
\text { технологічиої основи } \\
\text { підприємства }\end{array}$ & $\begin{array}{l}\text { Забезпечення високого рівия розвитку виробничо- } \\
\text { технологічиої бази підприємства та ефективного викорис- } \\
\text { тання його виробничих ресурсів. }\end{array}$ \\
\hline $\begin{array}{l}\text { Мотиваційиого } \\
\text { характеру }\end{array}$ & $\begin{array}{l}\text { Розроблення мотиваційного механізму створення, відбору } \\
\text { та реалізації інноваційних продуктів. } \\
\end{array}$ \\
\hline $\begin{array}{l}\text { Позитивного впливу } \\
\text { на генерування доданої } \\
\text { вартості }\end{array}$ & $\begin{array}{l}\text { Функціонування системи стратегічного управління при- } \\
\text { бутком повинно забезпечувати високий рівеиь ефективності } \\
\text { кожного етапу формування і розподілу доданої вартості у } \\
\text { формі прибутку. }\end{array}$ \\
\hline $\begin{array}{l}\text { Моніторингу умов } \\
\text { формування та розподілу } \\
\text { прибутку }\end{array}$ & $\begin{array}{l}\text { Створення частково децентралізованої системи стратегічного } \\
\text { моніторингу управління прибутком підприємства. }\end{array}$ \\
\hline $\begin{array}{l}\text { Колективиого } \\
\text { прийняття } \\
\text { управлінських рішень }\end{array}$ & $\begin{array}{l}\text { Формування уявлення про прийнятний аб́ бажаний об- } \\
\text { сяг генерування та отримання підприємством прибутку } \\
\text { має колективний суб'єктивний характер, що відображає } \\
\text { очікування фахівців, які приймають відповідні управлінські } \\
\text { рішення. }\end{array}$ \\
\hline $\begin{array}{l}\text { Децентралізації } \\
\text { управління }\end{array}$ & \begin{tabular}{|l} 
Децентралізація стратегічного управління прибутком на \\
основі прийняття ефективних управліпських рішень за \\
відповідними зонами стратегічних інтересів підприємства.
\end{tabular} \\
\hline
\end{tabular}

Джерело: побудовано автором на основі опрацьованих джерел 
Грунтуючись на тому положенні, що процес управління якістю прибутку являє собою сукупність відповідних організаційно-економічних заходів, важливо визначити алгоритм управління нею.

Важливим елементом удосконалення організаційних засад управління прибутком підприємства є формування відповідної організаційної структури на підприємстві, що відповідатиме меті нідвищення якості прибутку.

При цьому формуванні і реорганізації організаційної структури управління якістю прибутку підприємства вкрай важливо дотримуватись системного нідходу, який враховує стан та зміни зовнішніх та внутрішніх факторів впливу на фінансові результати діяльності підприємства.

Отже, можна відзначити, що організаційна структура підприємства, спрямована на задоволення вимог максимізації якості прибутку, повинна відповідати таким умовам: можливість оперативного реагування на вимоги ринку, здатність до впровадження інновацій; диверсифікація діяльності підприємства; орієнтація на максимізацію загальної якості (якості продукції та послуг, якості прибутку, якості діяльності всього підприємства); мінімізація ризиків, пов'язаних з організаційною структурою.

Елементами, що забезпечують управління величиною та якістю прибутку підприємства, $є$ аналіз рівня прибутковості у конкурентів, аналіз величини і якості прибутку підприємства, аналіз зовнішніх та внутрішніх факторів впливу на прибуток, оцінка узгодженості зі стратегією підприємства, оцінка раціональності формування системи “доход - витрати”, розроблення організаційно-економічного механізму управління величиною і якістю прибутку, оцінка узгодженості з планом розвитку нідприємства [14].

Виходячи із сучасних вимог економічного розвитку, а саме необхідності створення передумов задоволення потреб власників підприємства, нами запропоновано концепцію формування організаційно-економічного механізму управління якістю прибутку сучасного нідприємства, який спрямований на досягнення системної мети його діяльності (рис. 3).

Сутність концепції полягає в тому, що функціонування організаційно-економічного механізму управління величиною та якістю прибутку здійснюється у рамках стратегії і тактики управління прибутком підприсмства 3 дотриманням вимог нормативноправової бази, що регламентує формування, розподіл і використання операційного, інвестищійного і фінансового прибутку.

Для реалізації стратегії нідвищення величини і якості прибутку нідприємства нами розроблено організаційно-економічний механізм, який включає всі основні складові управління якістю прибутку: цілеполягання, стратегію і тактику, заходи, етапи, об'єкти, предмет, принципи, методи і орган такого управління.

Головна мета і завдання діяльності підприємства є опорними елементами управління прибутком підприсмства, оскільки вони формують засади управління підприємством і пов'язують зовнішні та внутрішні фактори цого діяльності.

Організаційні та економічні методи управління величиною та якістю прибутку тісно взаємопов'язані зі стратегією і тактикою управління прибутком, i здійснюються вони через орган управління, яким $є$ найвищі управлінські нідрозділи нідприємства. Важливими елементами вищенаведеного механізму $є$ предмет і об' єкти управління, приншипи і методи управління, заходи і етапи управління прибутком. Для прийняття відповідних управлінських рішень у межах організаційно-економічного механізму управління величиною та якістю приб̆утку нами запропоновано використовувати систему показників, що характеризують не тільки величину, а й якість прибутку, виконувати моніторинг формування, використання та розподілу прибутку підприємства, і $з$ урахуванням отриманих результатів здійснювати оцінювання і коригування управління величиною та якістю прибутку як складової частини нідвищення конкурентоспроможності підприємства.

Заходи щодо нідвищення якості прибутку можуть бути різноплановими, мати різний рівень складності, виконуватись різними нідрозділами підприємства. Можна відзначити, що більша частина заходів, що впроваджуються на нідприємстві, в разі дотримання вимог стосовно їх спрямованості на активну інноватизацію з метою досягнення перманентної та стійкої конкурентоспроможності можна класифікувати як заходи, спрямовані на нідвишення якості прибутку підприсмства. 


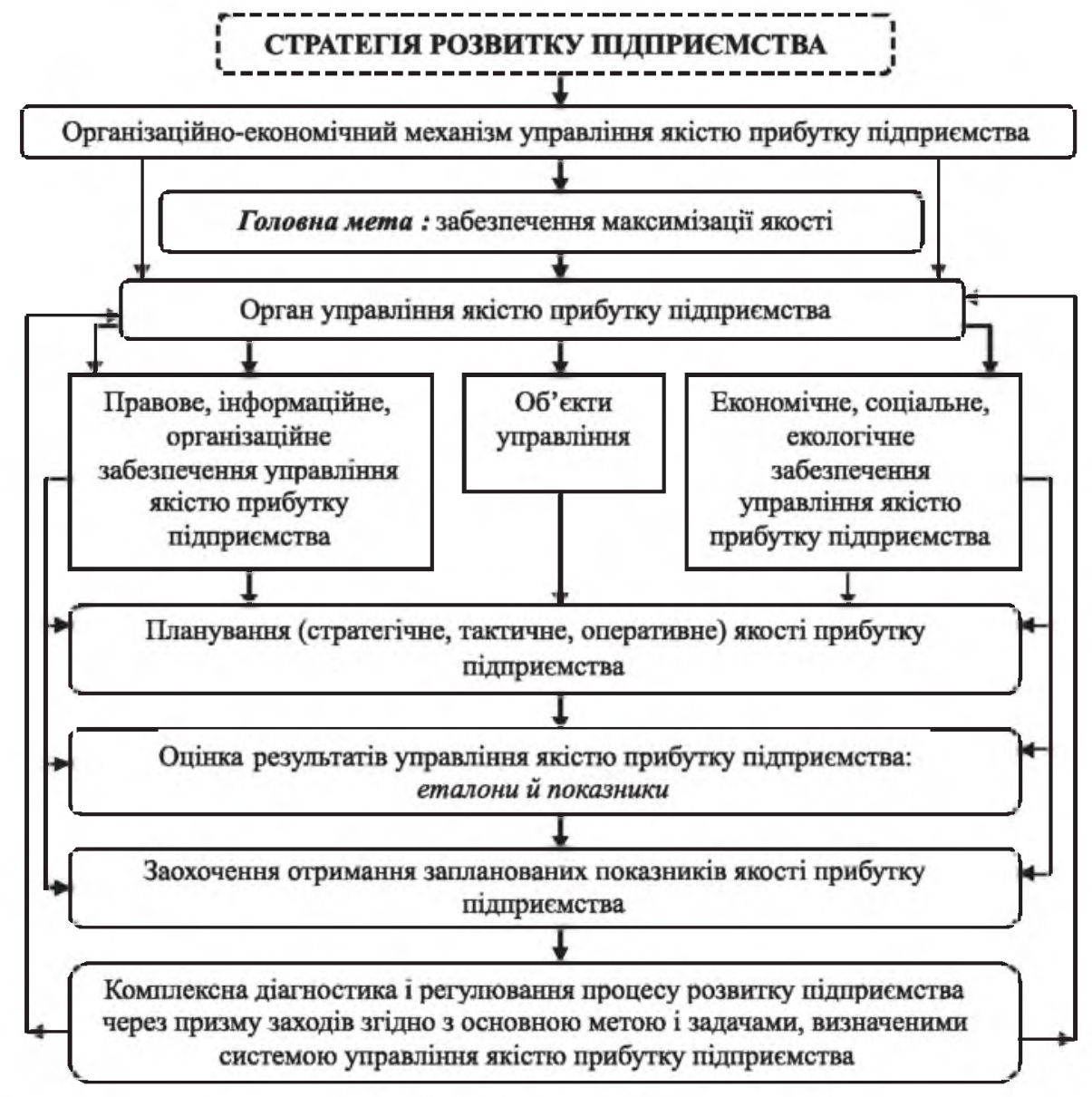

Рис. 3. Організаційно-економічний механізм управління якістю прибутку сучасного підприемства

Джерело: узагальнено та побу довано автором

Управлінські рішення щодо досягнення запланованої величини якості прибутку підприємства грунтуються на інформації. Відомо, що інформація - це перша ланка в будь-якій системі управління, у тому числі управління якістю прибутку підприємства. На величину якості прибутку підприємства впливають певні ризики при прийнятті управлінських рішень. Пов язані вони, насамперед, з недостатністю необхідної інформації. Тому дуже важливо приділяти цьому аспекту серйозну увагу. Для цього важливо класифікувати інформацію під визначений оргапізаційно-економічний механізм управління якістю прибутку підприємства: економічна, організаційна, техніко-економічна, соціальна, екологічна тощо.

Важливою складовою організаційно-економічного механізму управління якістю прибутку підприємства $є$ також оцінювання його результатів.

Втім, запропонований нами організаційно-економічний механізм управління якістю прибутку підприємства повинен змінюватися відповідно до вимог, що виникають у результаті розвитку суспільного виробництва, дії закону конкуренції тощо. Це означає, що організаційно-економічний механізм управління якістю прибутку підприємства постін̆но повинен удосконалюватись у всіх його елементах і деталях. Подальше удосконалення організаційно-економічного механізму управління якістю прибутку підприємства має спрямовуватися на пошук якісних змін у розвитку підприємства, забезпечуючи максимальну величину його кінщевих якісних результатів.

Іншими цінними критеріями, які необхідно враховувати у процесі формування стратегї управління прибутком підприємства, $є$ базова економічна стратегія та стадія 
життєвого циклу суб' єкта, які визначають ключові орієнтири реалізації управліиського впливу на прибуток підприємства для забезпечення підвищення прибутковості, ринкової вартості та економічного розвитку підприємства у довгостроковій перспективі (табл. 2).

Табличя 2

Формування стратегії управління прибутком сучасного підприємства

\begin{tabular}{|c|c|c|}
\hline $\begin{array}{c}\text { Етап життевого циклу } \\
\text { підприсмства }\end{array}$ & $\begin{array}{c}\text { Базова економічна } \\
\text { стратегія } \\
\text { підприсмства }\end{array}$ & $\begin{array}{c}\text { К. почові орісптирп стратегї } \\
\text { управлління прибутком } \\
\text { підприсмства }\end{array}$ \\
\hline $\begin{array}{l}\text { Формування та } \\
\text { становлення }\end{array}$ & & \multirow{2}{*}{$\begin{array}{l}\text { Підвищення якості прибутку в розрізі } \\
\text { процесів його формування, роз- } \\
\text { поділу та використання. Досягнення } \\
\text { цільового прибутку та фінансової } \\
\text { рівноваги підприємства. Забезпечення } \\
\text { стійкого підвищення прибутковості, } \\
\text { ін вестиційної приваблли вості та } \\
\text { економічного зростання підприємства. }\end{array}$} \\
\hline $\begin{array}{l}\text { Вік підприємства менше } \\
10 \text { років }\end{array}$ & Розвитку & \\
\hline Зростання & & \multirow[b]{2}{*}{$\begin{array}{l}\text { Зростання рівня якості прибутку в } \\
\text { розрізі процесів його формування, } \\
\text { розподілу, використання. Забезпе- } \\
\text { чення стійкого підвищення при- } \\
\text { бутковості, ринкової вартості, конку- } \\
\text { рентоспроможності підприємства. } \\
\text { Досягнення довгострокового еконо- } \\
\text { мічного розвитку підприємства. }\end{array}$} \\
\hline $\begin{array}{l}\text { Закрнплення позиції } \\
\text { підприємства на ринку, } \\
\text { темп зростання обсягу } \\
\text { реалізації перевищує } 15 \% \text {, } \\
\text { досягнення оптимального } \\
\text { рівня прибутковості }\end{array}$ & Розвитку & \\
\hline Зрілість & & \multirow[b]{2}{*}{$\begin{array}{l}\text { Підвищення якості прибутку в розрізі } \\
\text { процесів його формування, розподілу } \\
\text { та використання. Збереження фінан- } \\
\text { сової рівноваги підприємства. } \\
\text { Утримання (підв ищення) рівня } \\
\text { прибутковості. ринкової вартості та } \\
\text { конкурентоспроможності підпри- } \\
\text { ємства. } \\
\text { Забезпечення економічного зростання } \\
\text { (стабільності) та інвест иційної } \\
\text { привабливості підприємства. }\end{array}$} \\
\hline $\begin{array}{l}\text { Обсяг реалізації } \\
\text { зростає не більше ніж } \\
\text { на } 15 \% \text {, господарська } \\
\text { діяльність підприємства є } \\
\text { прибутковою }\end{array}$ & Стабілізації & \\
\hline Спад & & \multirow[b]{2}{*}{$\begin{array}{l}\text { Оптимізація якості прибутку в розрізі } \\
\text { процесів його формування, розподілу } \\
\text { і в и користан н я. Забез пе че нн я } \\
\text { максимально можливого рівня рента- } \\
\text { бельності (беззбиткової діяльності), } \\
\text { мінімального рівня збитковості. } \\
\text { Забезпечення стійкого підвищення } \\
\text { ефективності господарської діяль- } \\
\text { ності, раціоналізації величини витрат, } \\
\text { оптимальної мобілізації і реалізації } \\
\text { резервів підвищення прибутковості та } \\
\text { економічного зростання підприємства. }\end{array}$} \\
\hline $\begin{array}{l}\text { Зниження обсягів } \\
\text { реалізації та рівня } \\
\text { рентабельності } \\
\text { підприємства }\end{array}$ & Виживання & \\
\hline
\end{tabular}

Джерело: побудовано автором на основі опрацьованих джерел

Стратегічне управління прибутком підприємств $\epsilon$ не лише базовою, а й основною структурною складовою системи корпоративного менеджменту, яка значною мірою визначає ефективність функціонування останньої та впливає на успішність реалізації головної мети і ключових цілей підприємства, серед яких підвищення рівня прибутковості, ринкової вартості, досягнення фінансової рівноваги та економічного розвитку підприємства у довгостроковій перспективі. 
Новим підходом до прийняття управліиських рішень у сф)ері управління прибутком $\epsilon$ ситуаційний нідхід, який грунтується на припущенні, що придатність різних методів управління визначається різною ситуацією.

Системний підхід до управління прибутком передбачає вивчення способів організації нідсистем в одне ціле і впливу процесів, які відбуваються у системі в цілому, на окремі їі ланки. Слід зазначити, що система управління прибутком буде оптимальною тільки в тому разі, коли цілі кожної підсистеми визначатимуться цілями розвитку підприємства в цілому.

Політика управління формуванням прибутку повинна бути спрямована на максимізацію розміру позитивного фінансового результату через виконання комплексу завдань щодо забезпечення зростання обсягів діяльності, ефективного управління витратами, підвищення ефективності використання матеріально-технічної бази, оптимізації складу та структури обігових коштів, підвишення продуктивності праці та системи управління суб' єктом господарювання.

Ми переконані, що зростанню прибутку підприємства сприяє маніпулювання трьома змінними: прискоренням процесу реалізації; зменшенням маси витрат; збільшенням норми прибутку шляхом підвищення цін.

Висновки. Провідними шляхами покращення структури формування та розподілу прибутку підприємства $\epsilon$ визначення прюритетного напрямку використання прибутку. Це забезпечить майбутній розвиток підприємства, проведення аналізу динаміки та факторів отриманого прибутку, виявлення резервів, що сприятиме максимізації прибутку, а також ефективному плануванню формування, розподілу та використання прибутку на наступні перюди.

Запропонований нами організаційно-економічний механізм управління якістю прибутку підприємства - це система взаємопов 'язаних складових, кожна з яких виконує певні функції, однак усі вони працюють у комплексі для виконання однієї мети - досягнення відповідного рівня величини та якості прибутку.

Цей механізм повинен бути органічною складовою організаційно-економічного механізму управління підприємством. Це є запорукою мінімізації витрат на організацію управління, координації дій системи управління прибутком з усіма системами менеджменту нідприємства, підвищення взаємодії персоналу з метою виконання стратегічних планів підприємства.

\section{Список використаних джерел}

1. Бланк И. А. Управление прибылью. М.: Ника-Центр, Эльга, 2008. 512 с.

2. Брігхем Є. Ф. Основи фінансового менеджменту: підручник / Пер. 3 англ. К. Молодь, 1997. $1000 \mathrm{c}$.

3. Куц Л. Л. Капітал підприємства: формування та використання: опорн. консп. лекцій. Терноніль: ТНЕУ, 2012. 114 с.

4. Пігуль Н. Г. Управління прибутком підприємства // Проблеми і перспективи розвитку банківської системи України: зб. наук. пр. Д1НЗ "Українська академія банківської справи Національного банку України". 2010. Вип. 28. С. 79-85.

5. Поддєрьогін А. М., Бабіч В. В. Удосконалення обліку формування, розподілу та використання прибутку // Фінанси України. 2012. № 2. С. 103-110.

6. Покропивний С. Ф. Економіка підприємства: нідруч. 2-ге вид. перероб. та доп. К.: KHEУ, 2008. $528 \mathrm{c}$.

7. Олексюк О. І., Дзюбенко Л. М. Прибутковість в управлінні результативністю діяльності сучасних компаній // Фінанси України. 2006. № 12. С. 101-111.

8. Поддєрьогін А. М., Білик М. Д., Буряк Л. Д. Фінанси підприємств: нідруч. К.: KHEУ, 2006. $552 \mathrm{c}$.

9. Павлишенко М. М., Сивуля Л. А. Значення прибутку підприємства в ринковін̆ економгці [Електронний ресурc]. URL: http://www.nbuv.gov.ua/portal/chem_biol/ nvnltu/17_4/172_Pawlyszenko_17_4.pdf

10. Жигалкевич Ж. М., Фісенко Е. С. Система управління прибутком як умова ефективного функціонування підприємства [Електронний ресурс] // Економіка та суспільство. 2016. № 4. URL: http://economyandsociety.in.ua. - Заголовок з екрану.

11. Бойчук В. А., Проскурович О. В. Моделювання адаптивного управління прибутком підприємства // Вісник Хмельницького національного університету. 2010. № 1. T. 2. C. $71-76$. 
12. Костирко Л. А., Чернодубова Е. В. Фінансовий механізм забезпечення прибутковості підприємств: проблеми, інструменти, перспективи: моногр. Луганськ: Вид-во "Ноулідж", 2013. 180 с.

13. Нечитайло А. И. Бухгалтерский и налоговый учет прибыли. СПб.: Изд-во «Юридический центр Пресс», 2003. 326 с.

14. Економгічний аналіз: навч. посіб. / За ред. акад. НАН України проф. М. Г. Чумаченка. К.: КНЕУ, 2001. $256 \mathrm{c}$.

И. В.ФУРМАН,

кандидат экономических наук,

дочент кафедры административного менедюмента и альтернативных источников энергии,

Винниикий национальный аграрный университет

\section{Векторы повышения эффективности управления прибылью предприятия}

В статье раскрываюотся теоретико-методологические основы управления доходностью предприятий. Представлена экономическая природа прибыли и ее роль в обеспечении предпринимательской деятельности. Приведены особенности управления прибылью предприятий в современных условиях. Указаны векторы повымения эффективности управления прибылью предприятия.

Ключевые слова: прибыль, управление прибылью, управленческие ремения, финансовый результат деятельности предприятия, планирование прибыли, система управления прибылью, организационно-экономическиймеханизм управления качеством прибыли.

I. V. FURMAN,

PhD (Economics),

Associate Professor of Department for Administrative

Management and Alternative Energy Sources, Vinnytsya National Agrarian University

\section{Vectors for Increasing the Effectiveness of Profit Management at Company Level}

Imperfect management of processes involved in accumulation and disposal of profit at Ukrainian companies affects their performance, with the consequent losses of public budget revenues. This raises the need for new and more effective mechanisms for accumulation and disposal of corporate profit, which would be focused on maximal utilization of production, marketing and fiscal capacities of business entities and enhancement of their competitiveness at domestic and global market. The article is objective is to conduct theoretical study of profit as an economic category and an essential component of company's performance, sum up the principles of profit management, and analyze the profit management system at company level.

A brief review of theoretical definitions of profit is made, economic origin of profit and its role in business operation in the Ukrainian context is highlighted. The components of profit management system at company level, essential principles of strategic management of company profit, organizational and economic mechanism for company profit management, a strategy for profit management at company level is discussed and summed up. The organizational and economic mechanism for profit quality management at company level is proposed.

Keywords: profit, profit management, management decisions, financial result of company, profit planning, profit management system, organizational and economic mechanism for profit quality management.

Посилання на статтю:

Фурман I. В. Вектори підвищення ефективності управління прибутком підприємства // Науковий вісник Національної академії статистики, обліку та аудиту: зб. наук. пр. 2017. №3. С. 55-64. 